
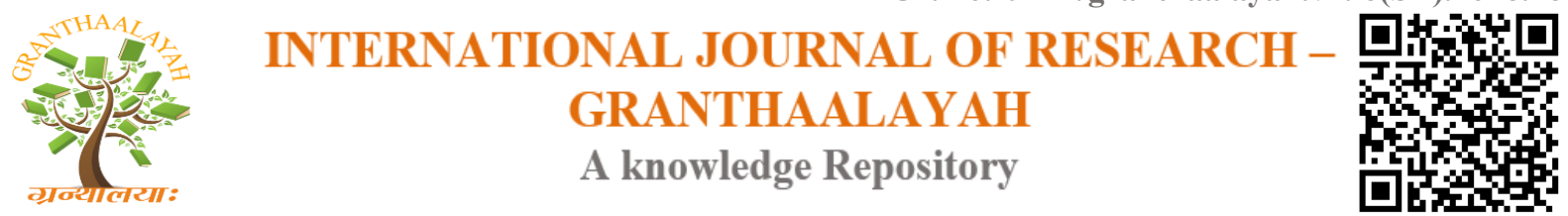

Management

\title{
A STUDY ON BUYERS PREFERENCE OF AMWAY PRODUCTS IN TIRUNELVELI
}

\author{
Dr. A.Hamil *1 (M.Com., M.Phil., SLET., Ph.D.), Ed.Priyadharshini ${ }^{2}$ (M.Com., SET., M.Phil.) \\ ${ }^{*}$ Associate Professor of Commerce and Research Guide, Sadakathullah Appa College \\ (Autonomous), Rahmath Nagar, Tirunelveli-627011, INDIA \\ ${ }^{2}$ Assistant Professor of Commerce and Ph.D Scholar (Part-time), Sadakathullah Appa College \\ (Autonomous), Rahmath Nagar, Tirunelveli-627011, INDIA
}

\begin{abstract}
Customers are the prime focus of any organization. The most important asset that any firm, can have is customers. An organization greatly depends on how many customers it has (customer base) how they buy and how often they buy. Satisfied customers usually buy more and buy frequently. Loyal customers also act best promotional source to new customers. They tend to bring in more and more new customers through word of mouth communication. It improves the market position of the firm and also the profits. This paper deals with the buyers' preference of amway products in Tirunelveli city.
\end{abstract}

Keywords:

Amway, customers, preference \& products.

Cite This Article: Dr. A.Hamil, and Ed.Priyadharshini, "A STUDY ON BUYERS PREFERENCE OF AMWAY PRODUCTS IN TIRUNELVELI" International Journal of Research - Granthaalayah, Vol. 4, No. 6: SE (2016): 34-47.

\section{INTRODUCTION}

Marketing is the process of creating or reorganizing an organization to be successful in selling a product or service that people not only desire, but are willing to buy. Therefore good marketing must be able to create a "proposition" or set of benefits for the end consumer. Shopper or customer that delivers value through products or services.

\section{STATEMENT OF PROBLEM}

Now days the customers can purchase any products, but the customer want to like the quality products. So quality is an important for any product. Branded products are most welcome by the customers, because the poor quality products may easily affect the health. So the customer prefers good quality products. Hence the present study has been undertaken to find out the important things as well as the expectation of the customers. In my study which is entitled as, "A 
STUDY ON BUYERS PREFERENCE OF AMWAY PRODUCTS IN TIRUNELVELI'. I focus the customer's preference towards Amway products.

\section{OBJECTIVES OF THE STUDY}

- To study the factors influencing the customer preference towards Amway products.

- To study the customer satisfaction towards the consumption of the products.

- To find out the problems faced by the consumer and give suggestions on the basis of the study.

- To discuss briefly on quality and rates of Amway products.

- To analysis the demographic variables such as age, gender, education \& income.

- To measure the level of opinion towards Amway products.

\section{SCOPE OF THE STUDY}

The scope of the study extends to the following related aspects viz factors influencing the customer's preference regarding this Amway products and also the satisfaction level of the consumers regarding this product and the problems faced by the consumers in purchasing and using of Amway products. The data has been collected based on the questionnaire schedule. Though the main scope of this study is to analyze the problems faced by the consumers by using Amway products.

\section{LIMITATIONS OF THE STUDY}

Many researchers have made studies on Amway products. Research on Amway products was worth rating carefully analysis and critical enquiry an attempt has made to study the consumer preference of Amway products. There are a number of products and they are playing a vital role in satisfying the thirst and needs of an individual consumers. By making an attempt to study the consumer preferences, a number of inferences can be found so that extends of satisfaction can also be desired. Brand preference of products may vary from group to group and also from individual persons.

\section{RESEARCH DESIGN}

Samples are representatives of the universe. The findings from the samples can be taken as the opinion of all respondents. The data cannot be collected from each and every person. Hence I take the sample as 75 .

The data needed for the project consist of 2 .

a) Primary data

b) Secondary data

Primary data is that data which collected from primary sources by using a schedule of questionnaire consisting of 34 question. Simple random sampling has been applied for data collection. 
The secondary data is collected from books, reports, journals and websites. Only supportive secondary data is included.

\section{AREA OF THE STUDY}

Area of the study of project is Tirunelveli city.

\section{PERIOD OF THE STUDY}

Period of the study of project is December 2015 to April 2016.

\section{STATISTICAL TOOLS USED}

The data collected has been analyzed with the help of various tools and techniques to fulfill the research objectives. The statistical tools applied for the project is

a) Percentage analysis

b) Weighted average method

c) Garrett ranking

d) Hypothesis Framed and tested by Chi-Square test

The hypothesis is: There is no significant difference between the urban and rural buyers on the level of satisfaction.

Table 1: Type of Loyalty towards AMWAY products

\begin{tabular}{|l|l|l|l|}
\hline Sl. No & Type of loyalty towards Amway products & No. of. Respondents & Percent \\
& & & \\
\hline 1 & Yes & 52 & 69.3 \\
\hline 2 & No & 23 & 30.7 \\
\hline & Total & 75 & 100 \\
\hline
\end{tabular}

Source: Primary Data

From the above table 1 , it reveals that $69.3 \%$ of the respondents are the brand loyal customers and $30.7 \%$ of the respondents are not the brand loyal customers. So, it concludes that most of the respondents are the brand loyal customers of Amway products.

Table 2: Type of buyer of AMWAY products

\begin{tabular}{|l|l|l|l|}
\hline Sl. No & Type of buyer of Amway Products & No. of. Respondents & Percent \\
\hline 1 & Frequent buyer & 25 & 33.3 \\
\hline 2 & Normal buyer & 29 & 38.7 \\
\hline 3 & Occasional buyer & 9 & 12.0 \\
\hline 4 & Rare buyer & 12 & 16.0 \\
\hline & Total & 75 & 100 \\
\hline
\end{tabular}

Source: Primary Data 
From the above table 2, it concludes that $38.7 \%$ of the buyers are Normal buyer and $33.3 \%$ of the buyers are frequent buyer. So, it concludes that majority of the buyers are buying the product normally.

Table 3: SOURCE OF INFORMATION

\begin{tabular}{|l|l|l|l|}
\hline Sl. No & Source of information about Amway products & No. of. Respondents & Percent \\
\hline 1 & Friends \& relatives & 46 & 61.3 \\
\hline 2 & Newspaper & 8 & 10.7 \\
\hline 3 & Magazines & 3 & 4.0 \\
\hline 4 & Television & 3 & 4.0 \\
\hline 5 & Personal selling & 8 & 10.7 \\
\hline 6 & Internet & 7 & 9.3 \\
\hline 7 & Others & 0 & 0 \\
\hline & Total & 75 & 100 \\
\hline
\end{tabular}

Source: Primary Data

From the above table 3, it shows that $61.3 \%$ of the respondents are come to know about the product information from friends \& relatives and $10.7 \%$ of the respondents are come to know about the product information from newspaper. So it finalised that most of the respondents come to know about the information from friends and relatives.

Table 4: Monthly average purchase of AMWAY products

\begin{tabular}{|l|l|l|l|}
\hline Sl. No & Monthly average purchase of Amway products & No. of. Respondents & Percent \\
\hline 1 & Below Rs.2,000 & 37 & 49.3 \\
\hline 2 & Rs.2,000-4,000 & 18 & 24.0 \\
\hline 3 & Rs.4,001 -6,000 & 9 & 12.0 \\
\hline 4 & Above Rs.6,000 & 11 & 14.7 \\
\hline & Total & 75 & 100 \\
\hline
\end{tabular}

Source: Primary Data

From the above table 4 , it reveals that $49.3 \%$ of the buyers are purchasing the Amway products below Rs. 2,000 and 24\% of the buyers are purchasing the Amway products Rs.2,000-4,000. So, it finalised that majority of the buyers are purchasing the product below Rs.2,000.

Table 5: Inhibition while buying AMWAY products for the first time

\begin{tabular}{|l|l|l|l|}
\hline Sl. No & Inhibition while buying Amway products & No. of. Respondents & Percent \\
\hline 1 & Yes & 46 & 61.3 \\
\hline 2 & No & 29 & 38.7 \\
\hline & Total & 75 & 100 \\
\hline
\end{tabular}

Source: Primary Data

From the above table 5, it shows that $61.3 \%$ of the buyers are inhibited while buying Amway products for the first time and $38.7 \%$ of the buyers are not inhibited while buying Amway products for the first time. So, it concludes that most of the buyers are inhibited while buying the products for the first time. 
Table 5.1: Reason for inhibition to buy AMWAY products

\begin{tabular}{|l|l|l|l|}
\hline Sl. No & Reason for inhibition to buy Amway products & No. of. Respondents & Percent \\
\hline 1 & Financial constraints & 11 & 23.9 \\
\hline 2 & Prices are higher & 18 & 39.1 \\
\hline 3 & Unreliability & 9 & 19.6 \\
\hline 4 & Unaware of the quality & 8 & 17.4 \\
\hline & Total & 46 & 100 \\
\hline
\end{tabular}

Source: Primary Data

From the above table 5.1, it observes that $39.1 \%$ of the buyers are inhibited due to prices are higher and $23.9 \%$ of the buyers are inhibited due to financial constraints. So, it finalised that majority of the respondents are inhibited to buy Amway products due to prices are higher.

Table 6: Weighted Garrett Score and Garrett Ranks on factors that motivated to buy the Amway products in the Respondents attention

\begin{tabular}{|l|l|l|l|}
\hline Sl. No & Particulars & Mean score & Rank \\
\hline 1 & Prices are comparatively lower & 50.12 & V \\
\hline 2 & Uniqueness & 54.13 & III \\
\hline 3 & Quality & 62.29 & I \\
\hline 4 & Brand image & 57.05 & II \\
\hline 5 & Attractive package & 53.75 & IV \\
\hline 6 & Discount offer & 48.29 & VI \\
\hline 7 & Advertisement & 41.77 & VII \\
\hline 8 & Compulsion of the sales representative & 40.08 & VIII \\
\hline 9 & Others & 38.773 & IX \\
\hline
\end{tabular}

Source: Computed Primary data

Quality is the factor got the first rank. Brand Image was ranked by second. The impression in the mind of the consumers is brand's total personality. Uniqueness was ranked by third by the respondents. Attractive package scored fourth rank by the respondents. Price was ranked by fifth by the respondents. Discount offer scored by sixth. Amway launched all products with discounts and giving offers for specific products. Advertisement got seventh rank by the respondents. It means to announce the product, service etc in some public medium of communication in order to induce people to buy or use the products. Compulsion of the sales representative was ranked by eighth by the respondents. Other factor was ranked by ninth by the respondents.

Table 7: Weighted Garrett Score and Garrett Ranks on Opinion of Categorizing The Amway Products

\begin{tabular}{|l|l|l|l|}
\hline $\begin{array}{l}\text { Sl. } \\
\text { No }\end{array}$ & Particulars & $\begin{array}{l}\text { Mean } \\
\text { score }\end{array}$ & Rank \\
\hline 1 & $\begin{array}{l}\text { Nutrition and } \\
\text { wellness }\end{array}$ & 53.12 & I \\
\hline 2 & Beauty & 48.6 & IV \\
\hline 3 & Home care & 52.35 & II \\
\hline 4 & Personal care & 49.72 & III \\
\hline
\end{tabular}


Source: Computed Primary data

\begin{tabular}{|l|l|l|l|}
\hline 5 & Others & 44.21 & $\mathbf{V}$ \\
\hline
\end{tabular}

Nutrition scored the first rank. Then the home care got second rank and personal care secured third rank and beauty got forth rank and others secured fifth rank.

Table 8: Period of using AMWAY products

\begin{tabular}{|l|l|l|l|}
\hline Sl. No & Period of using Amway products & No. of. Respondents & Percent \\
\hline 1 & Less than 1 year & 22 & 29.3 \\
\hline 2 & 1 to 2 years & 26 & 34.7 \\
\hline 3 & 3 to 4 years & 18 & 24.0 \\
\hline 4 & 5 to 6 years & 5 & 6.7 \\
\hline 5 & More than 6 years & 4 & 5.3 \\
\hline & Total & 75 & 100 \\
\hline
\end{tabular}

Source: Primary Data

From the above table 8 , it finds that, $34.7 \%$ of the buyers are using the product on 1 to 2 years and $29.3 \%$ of the buyers are using the product on less than 1 year. So, it finalised that majority of the buyers are using the product on the period of 1 to 2 years.

Table 9: Place of buying AMWAY products

\begin{tabular}{|l|l|l|l|}
\hline Sl. No & Place of buying Amway products & No. of. Respondents & Percent \\
\hline 1 & Directly from the company & 31 & 41.3 \\
\hline 2 & Retail outlet & 10 & 13.3 \\
\hline 3 & Online shopping & 13 & 17.3 \\
\hline 4 & Marketing agents & 21 & 28.0 \\
\hline & Total & 75 & 100 \\
\hline
\end{tabular}

\section{Source: Primary Data}

From the above table 9, it reveals that $41.3 \%$ of the respondents are buying the Amway products through directly from the company and $28 \%$ of the respondents are buying the Amway products through marketing agents. So, it concludes that most of the respondents are buying the products directly from the company.

Table 10: Opinion on switching over from AMWAY products in the near future

\begin{tabular}{|c|c|c|c|}
\hline $\begin{array}{l}\text { Sl. } \\
\text { No }\end{array}$ & $\begin{array}{l}\text { Opinion on switching over from Amway products in } \\
\text { the near future }\end{array}$ & $\begin{array}{ll}\text { No. } & \text { of. } \\
\text { Respondents }\end{array}$ & Percent \\
\hline 1 & Certainly Not & 12 & 16.0 \\
\hline 2 & No & 41 & 54.7 \\
\hline 3 & May be & 11 & 14.7 \\
\hline 4 & Yes & 9 & 12.0 \\
\hline 5 & Certainly & 2 & 2.6 \\
\hline & Total & 75 & 100 \\
\hline
\end{tabular}

Source: Primary Data 
From the above table 10, it expresses that, $54.7 \%$ of the respondents are not at all switching the Amway products in the near future and $16 \%$ of the respondents says that certainly not. So it concluded that majority of the respondents are not all switching the Amway products in the near future.

Table 11: Opinion on the superiority of the branded products than the non-branded products

\begin{tabular}{|l|l|l|l|}
\hline $\begin{array}{l}\text { Sl. } \\
\text { No }\end{array}$ & $\begin{array}{l}\text { Opinion on the superiority of the branded products } \\
\text { than the non-branded products }\end{array}$ & $\begin{array}{l}\text { No. } \\
\text { Respondents }\end{array}$ & Percent \\
\hline 1 & Yes & 61 & 81.3 \\
\hline 2 & No & 14 & 18.7 \\
\hline & Total & 75 & 100 \\
\hline
\end{tabular}

Source: Primary Data

From the above table 11, it shows that $81.3 \%$ of the buyers prefers the branded products than the non-branded products and $18.7 \%$ of the buyers are not prefer the branded products than the nonbranded products. So it finalized that majority of the buyers prefers the branded products than the non-branded products.

Table 12: Opinion on the easy availability of the AMWAY products

\begin{tabular}{|l|l|l|l|}
\hline $\begin{array}{l}\text { Sl. } \\
\text { No }\end{array}$ & $\begin{array}{l}\text { Opinion on the easy availability of the Amway } \\
\text { products }\end{array}$ & $\begin{array}{l}\text { No. } \\
\text { Respondents }\end{array}$ & Percent \\
\hline 1 & Yes & 55 & 73.3 \\
\hline 2 & No & 20 & 26.7 \\
\hline & Total & 75 & 100 \\
\hline
\end{tabular}

Source: Primary Data

From the above table 12 , it observes that $73.3 \%$ of the buyers says that Amway products are easily available and $26.7 \%$ of the buyers says that the products are not easily available. So it concludes that most of the buyers have opinion about easy availability of the Amway products.

Table 13: Appreciation of AMWAY products by others

\begin{tabular}{|l|l|l|l|}
\hline Sl. No & Appreciation of AMWAY products & No. of. Respondents & Percent \\
\hline 1 & Yes & 58 & 77.3 \\
\hline 2 & No & 17 & 22.7 \\
\hline & Total & 75 & 100 \\
\hline
\end{tabular}

Source: Primary Data

From the above table 13, it shows that $77.3 \%$ of the respondents are appreciated the Amway products and $22.7 \%$ of the respondents are not appreciated the Amway products. So it concludes that most of the respondents are appreciated the Amway products.

Table 14: Period taken to deliver AMWAY products

\begin{tabular}{|l|l|l|l|}
\hline Sl. No & Period taken to deliver Amway products & No. of. Respondents & Percent \\
\hline 1 & Less than 24 hours & 19 & 25.3 \\
\hline 2 & Between 1 \& 2 days & 32 & 42.7 \\
\hline 3 & Over 3 days & 18 & 24.0 \\
\hline
\end{tabular}




\begin{tabular}{|l|l|l|l|}
\hline 4 & More than one week & 6 & 8.0 \\
\hline & Total & 75 & 100 \\
\hline
\end{tabular}

Source: Primary Data

From the above table 14, it reveals that, $42.7 \%$ of the buyers says that the Amway products are delivered between $1 \& 2$ days and $25.3 \%$ of the buyers says that the Amway products are delivered with the period of less than 24 hours. So, it finalised that most of the buyers are satisfied the period taken to deliver the Amway products.

Table 15: Level of satisfaction on the grievance redressal mechanism with Amway

\begin{tabular}{|l|l|l|l|}
\hline $\begin{array}{l}\text { Sl. } \\
\text { No }\end{array}$ & $\begin{array}{l}\text { Level of satisfaction on the grievance redressal } \\
\text { mechanism with Amway }\end{array}$ & $\begin{array}{l}\text { No. } \\
\text { Respondents }\end{array}$ & Percent \\
\hline 1 & Highly satisfied & 22 & 29.3 \\
\hline 2 & Satisfied & 46 & 61.3 \\
\hline 3 & Neither satisfied nor dissatisfied & 3 & 4.0 \\
\hline 4 & Dissatisfied & 4 & 5.3 \\
\hline 5 & Highly dissatisfied & 0 & 0 \\
\hline & Total & 75 & 100 \\
\hline
\end{tabular}

Source: Primary Data

From the above table 15 , it finds that $61.3 \%$ of the respondents are satisfied and $29.3 \%$ of the respondents are highly satisfied. So, it concludes that majority of the respondents are satisfied with the grievance redressal mechanism with Amway.

Table 16: Opinion on the quality of Amway products compared to other similar products

\begin{tabular}{|l|l|l|l|}
\hline $\begin{array}{l}\text { Sl. } \\
\text { No }\end{array}$ & $\begin{array}{l}\text { Opinion the quality of Amway products compared to } \\
\text { other similar products }\end{array}$ & $\begin{array}{l}\text { No. } \\
\text { Respondents }\end{array}$ & Percent \\
\hline 1 & Strongly agree & 26 & 34.7 \\
\hline 2 & Agree & 33 & 44.0 \\
\hline 3 & Neither agree nor disagree & 4 & 5.3 \\
\hline 4 & Disagree & 12 & 16.0 \\
\hline 5 & Strongly disagree & 0 & 0 \\
\hline & Total & 75 & 100 \\
\hline
\end{tabular}

Source: Primary Data

From the above table 16, it reveals that $44 \%$ of the buyers says that quality of Amway products compared to other similar products is accepted as agree and $34.7 \%$ of the buyers says that quality of Amway products compared to other similar products is accepted as strongly agree. So it concludes that majority of the buyers says that Amway products is regarded as quality products compared to other similar products.

Table 17: Alternate make likely to buy

\begin{tabular}{|l|l|l|l|}
\hline Sl. No & Alternate make likely to buy & No. of. Respondents & Percent \\
\hline 1 & Lakme & 9 & 12.0 \\
\hline
\end{tabular}




\begin{tabular}{|l|l|l|l|}
\hline 2 & Yardley & 17 & 22.7 \\
\hline 3 & Himalaya & 20 & 26.7 \\
\hline 4 & Hindustan unilever & 21 & 28.0 \\
\hline 5 & Others & 8 & 10.7 \\
\hline & Total & 75 & 100 \\
\hline
\end{tabular}

Source: Primary Data

From the above table 17 , it makes it clear that $28 \%$ of the respondents are prefer to buy Hindustan unilever and $26.7 \%$ of the respondents are prefer to buy Himalaya. So, it finalised that most of the respondents prefer to buy the Hindustan unliever products.

Table 18: Quantum of AMWAY products bought

\begin{tabular}{|l|l|l|l|}
\hline Sl. No & Quantum of AMWAY products bought & No. of. Respondents & Percent \\
\hline 1 & In bulk & 43 & 57.3 \\
\hline 2 & Single piece & 32 & 42.7 \\
\hline & Total & 75 & 100 \\
\hline
\end{tabular}

Source: Primary Data

From the above table 18, it observes that $57.3 \%$ of the buyers are buying the Amway products in bulk and $42.7 \%$ of the buyers are buying the Amway products in single piece. So it concludes that majority of the buyers are buying the Amway products in bulk.

Table 19: Suggestion of AMWAY products to friends and relatives

\begin{tabular}{|l|l|l|l|}
\hline $\begin{array}{l}\text { Sl. } \\
\text { No }\end{array}$ & $\begin{array}{l}\text { Suggestion of Amway products to friends and } \\
\text { relatives }\end{array}$ & $\begin{array}{l}\text { No. } \\
\text { Respondents }\end{array}$ & Percent \\
\hline 1 & Certainly & 20 & 26.7 \\
\hline 2 & Yes & 43 & 57.3 \\
\hline 3 & May be & 8 & 10.7 \\
\hline 4 & No & 3 & 4.0 \\
\hline 5 & Certainly Not & 1 & 1.3 \\
\hline & Total & 75 & 100 \\
\hline
\end{tabular}

Source: Primary Data

From the above table 19, it reveals that $57.3 \%$ of the buyers recommend the Amway products to their friends and relatives and $26.7 \%$ of the respondents say that certainly. So it finalised that most of the respondents are recommend the Amway products to friends and relatives.

Table 20: Type of package of AMWAY products likely to buy

\begin{tabular}{|l|l|l|l|}
\hline Sl. No & $\begin{array}{l}\text { Type of package of AMWAY products likely to } \\
\text { buy }\end{array}$ & $\begin{array}{l}\text { No. } \\
\text { Respondents }\end{array}$ & Percent \\
\hline 1 & Packet & 35 & 46.7 \\
\hline 2 & Container & 40 & 53.3 \\
\hline & Total & 75 & 100 \\
\hline
\end{tabular}

Source: Primary Data 
From the above table 20, it shows that $53.3 \%$ of the respondents are buying the products in container and $46.7 \%$ of the respondents are buying the products in packet. So it concludes that majority of the respondents are buying the products in container.

Table 21: Ranking of Opinion on Level of Satisfaction about the Amway Products

\begin{tabular}{|l|l|l|}
\hline Sl. No & Particulars & Weighted average \\
\hline 1 & Using Amway products make one self confident & 4.21 \\
\hline 2 & Amway products improve quality of life & 4.01 \\
\hline 3 & Amway products are eco-friendly & 3.85 \\
\hline 4 & It provides good business opportunity & 3.87 \\
\hline 5 & It is an international brand & 4.15 \\
\hline 6 & Prices are comparatively reasonable & 3.89 \\
\hline 7 & Amway products comparatively harmless & 3.947 \\
\hline 8 & It provides self esteem & 3.787 \\
\hline 9 & Performance activities are sufficient & 4.04 \\
\hline 10 & It provides sophistication to oneself & 3.787 \\
\hline 11 & Amway websites are user friendly for online buyers & 3.627 \\
\hline
\end{tabular}

Source: Computed Primary Data

Using Amway products make one self-confident, It is an international brand, Performance activities are sufficient and Amway products improve quality of life are the opinion are agreed by the respondents, because it scored 4.21, 4.15, 4.04 and 4.01 respectively. And also Amway products comparatively harmless, Prices are comparatively reasonable, It provides good business opportunity, Amway products are eco-friendly, It provides self-esteem, It provides sophistication to oneself and Amway websites are user friendly for online buyers are also agreed it scored 3.94, $3.89,3.86,3.85,3.7,3.7$, and 3.62 respectively.

Table 22: Number of Responses on Ranking of Satisfaction on the factors of Amway Product

\begin{tabular}{|l|l|l|l|}
\hline $\begin{array}{l}\text { Sl. } \\
\text { No }\end{array}$ & & $\begin{array}{l}\text { Total } \\
\text { Score }\end{array}$ & Mean \\
\hline 1 & Price & 307 & 4.09 \\
\hline 2 & Quality & 325 & 4.33 \\
\hline 3 & Brand image & 306 & 4.08 \\
\hline 4 & Familiarity & 299 & 3.987 \\
\hline 5 & Availability & 303 & 4.04 \\
\hline 6 & Varieties & 293 & 3.907 \\
\hline 7 & Attractive package & 304 & 4.05 \\
\hline 8 & Discount or Gift & 282 & 3.76 \\
\hline 9 & Measurement & 288 & 3.84 \\
\hline 10 & Advertisement & 275 & 3.67 \\
\hline
\end{tabular}

Source: Computed Primary data

Quality is the factor got the highest score 4.3 it denotes the respondents agreed the amway products are quality in nature. Price and Brand image are secured almost nearest mean respectively 4.09 and 4.08 these factors are agreed by the respondents on the amway. And then the Attractive package and the availability are the factors got the nearest mean is like 4.05 and 
4.04 so it is agreed by the respondents. Familiarity, Varieties, measurement of the product, discount or gift and advertisement are the factors got the mean value above 3.6 so it is also got agreed level.

Table 23: Opinion on the accuracy and honesty of Amway products in terms of information provided

\begin{tabular}{|l|l|l|l|}
\hline $\begin{array}{l}\text { Sl. } \\
\text { No }\end{array}$ & $\begin{array}{l}\text { Opinion on the accuracy and honesty of Amway } \\
\text { products in terms of information provided }\end{array}$ & $\begin{array}{l}\text { No. } \\
\text { Respondents }\end{array}$ & Percent \\
\hline 1 & Excellent & 26 & 34.7 \\
\hline 2 & Good & 32 & 42.7 \\
\hline 3 & Neither good nor bad & 9 & 12.0 \\
\hline 4 & Bad & 2 & 2.6 \\
\hline 5 & Worst & 6 & 8.0 \\
\hline & Total & 75 & 100 \\
\hline
\end{tabular}

Source: Primary Data

From the above table 23 , it reveals that $42.7 \%$ of the respondents says that the accuracy and honesty of Amway products in terms of information provided is good and $34.7 \%$ of the buyers says that the accuracy and honesty of Amway products in terms of information provided is excellent. So, it finalised that most of the respondents says that accuracy and honesty of Amway products is good.

Table 24: Opinion on improvement needed on AMWAY products

\begin{tabular}{|l|l|l|l|}
\hline $\begin{array}{l}\text { SI. } \\
\text { No }\end{array}$ & $\begin{array}{l}\text { Opinion on improvement needed on AMWAY } \\
\text { products }\end{array}$ & $\begin{array}{l}\text { No. } \\
\text { Respondents }\end{array}$ & Percent \\
\hline 1 & Yes & 49 & 65.3 \\
\hline 2 & No & 26 & 34.7 \\
\hline & Total & 75 & 100 \\
\hline
\end{tabular}

Source: Primary Data

From the above table 24, it shows that $65.3 \%$ of the buyers says that the improvement needed on Amway products and $34.7 \%$ of the buyers are not. So it concludes that majority of the buyers says that the improvement needed on Amway products.

Table 25: Overall satisfaction Level on AMWAY Products

\begin{tabular}{|l|l|l|}
\hline Level of satisfaction & Frequency & Percentage \\
\hline Highly satisfied & 37 & 49.3 \\
\hline Satisfied & 33 & 44.0 \\
\hline Neutral & 5 & 6.7 \\
\hline \multicolumn{1}{|c|}{ Total } & 75 & 100.0 \\
\hline
\end{tabular}

\section{Source: Primary Data}

$49.3 \%$ of respondents are highly satisfied on all factors of the amway products. And $44 \%$ of respondents are satisfied. $6.7 \%$ respondents are in neutral level of satisfaction. 
H01 There is no significant difference between the urban and rural buyers on the level of satisfaction.

Table 26: F-Test

\begin{tabular}{|l|l|l|l|l|l|}
\hline Particulars & Sum of Squares & Mean Square & F & Sig. \\
\hline Between Groups & .002 & 1 & .002 & .006 .940 \\
\hline Within Groups & 28.344 & 73.388 & & \\
\hline Total & 28.347 & 74 & & & \\
\hline
\end{tabular}

Source: Computed Primary data

The significance level is more than 0.5 so, there is the null hypothesis is accepted. Therefore there is no association between the urban and rural buyers on the level of satisfaction. So, all of the customers are satisfied whether they may be in rural or urban.

\section{FINDINGS AND CONCLUSIONS}

- Most of the respondents are male in the study area.

- Majority of the persons are located in rural area who come to the city to buy the products.

- It concludes that people in the age group of 20-30 years prefer to buy the products.

- Most of the persons comes under other categories. Hence it is clear that all the people prefer Amway products.

- $41.3 \%$ of the respondents have school level qualification.

- Majority of the persons follow nuclear family setup which provides the way for savings and chances for making more purchases.

- Most of the respondents family size is upto the level of 5.

- It concludes that majority of the respondents have own house.

- $69.3 \%$ of the buyers are the brand loyal customers of Amway products.

- $38.7 \%$ of the respondents are the normal buyer of Amway products. They prefer to buy the products normally.

- It concludes that majority of the buyers have come to know about information of Amway products from friends and relatives.

- About half of the buyers have purchasing their product in an monthly average of below Rs.2,000.

- $61.3 \%$ of the buyers are inhibited while buying Amway products for the first time.

- Less than $1 / 2$ of the buyers are not inhibited while buying Amway products for the first time.

- Majority of the buyers are satisfied the quality of Amway products.

- Most of the buyers are satisfied the nutritional products of Amway.

- $34.7 \%$ of the buyers are using the Amway product on 1 to 2 years.

- $41.3 \%$ of the respondents are buying the Amway products through directly from the company.

- It concludes that $81.3 \%$ of the buyers prefers the branded products than the non branded products.

- It expresses that $73.3 \%$ of the buyers says that the Amway products are easily available.

- Most of the respondents says that the Amway products are appreciated by others. 
- $42.7 \%$ of the buyers are satisfied the period taken to deliver the Amway products.

- More than half of the buyers are satisfied with the grievance redressal mechanism with Amway.

- $44 \%$ of the buyers says that Amway products is regarded as quality products compared to other similar products.

- It concludes that majority of the respondents prefer to buy the Hindustan unlilever products.

- It expresses that $57.3 \%$ of the buyers are buying the Amway products in bulk quantity.

- More than half of the buyers will suggest the Amway products to friends and relatives.

- $53.3 \%$ of the respondents are buying the Amway products in container.

- Majority of the buyers says that accuracy and honesty of Amway products is good.

- It concludes that $65.3 \%$ of the buyers say that the improvement needed on Amway products.

\section{SUGGESTIONS}

1) To announce the products in some public medium of communication in order to induce people to buy the products.

2) Some improvement should be needed on Amway products.

3) To reduce the price of the Amway products, because the price is high.

4) Delays the delivery of the products. So it should be needed the improvement.

5) All the products are not available in packet. So it should also be improved.

6) The product should also be launched in urban area, because they should come to the city to buy the products.

7) The products are not easily available in all places. So it should also be improved.

\section{CONCLUSION}

The present study reveals that the consumer preference towards the Amway products. They are mainly motivated by the quality of the products. The popularity of the brand also one of the factors urged by the consumers for their purchase decision. Overall, it can be concluded that consumers are satisfied with the quality and vitamin contents of products but they expect more on reasonable price.

\section{REFERENCE}

[1] Akbar, M. M., \& Parvez, N. (2009). Impact of service quality, trust, and customer satisfaction on customers' loyalty. ABAC Journal, 29(1).

[2] Chakraborty, S., \& Sengupta, K. (2014). Structural equation modelling of determinants of customer satisfaction of mobile network providers: Case of Kolkata, India. IIMB Management Review, 26(4), 234-248.

[3] Divya, A., \& Regi, B. An Empirical Study on Effectiveness of Social Media as a Marketing Tool.

[4] Dr. C. Eugine Franco, and Regi. S Bulomine, "ADVANTAGES AND CHALLENGES OF E-COMMERCE CUSTOMERS AND BUSINESSES: IN INDIAN PERSPECTIVE” International Journal of Research - Granthaalayah, Vol. 4, No. 3: SE (2016): 7-13. 
[5] Golden, S. A. R. (2015). Regional Imbalance affecting quality of e-banking services with special reference to Tuticorin District-An Analysis. International Journal of Research, 2(3), 788-798.

[6] Golden, S. A. R., \& Regi, S. B. (2015). Satisfaction of Customers towards User Friendly Technological Services offered by Public and Private Sector banks at Palayamkottai, Tirunelveli District. International Journal of Research, 2(3), 775-787.

[7] Golden, S. A. R., \& Regi, S. B. Mobile Commerce in Modern Business Era.

[8] Negi, R. (2009). DETERMINING CUSTOMER SATISFACTION THROUGH PERCEIVED SERVICE QUALITY: A STUDY OF ETHIOPIAN MOBILE USERS. International Journal of Mobile Marketing, 4(1).

[9] Regi, S. B. \& S, A. R. G. (2014). "A DESCRIPTIVE STUDY ON THE ROLE OF CONSUMER PSYCHOLOGY AND BEHAVIOUR IN PRODUCT PURCHASING". Indian Streams Research Journal, 3.

[10] Regi, S. B., \& Golden, S. A. R. (2014). Attitude of Rural People Towards Technology Inclusion In Banking Services At Tirunelveli District. IGJAE - Indo Global Journal Of Applied Management Science, 2(2).

[11] Smaila, I., A. Divya, and S. Bulomine Regi. "An Empirical Study on Significant Role of Solar Energy Products in this Modern Era. 